\title{
Autophagy-dependent danger signaling and adaptive immunity to poorly immunogenic tumors
}

\author{
Guido Kroemer ${ }^{1,2,3,4,5,6,7}$ and Lorenzo Galluzzi $\mathbf{1}^{1,2,3,4,8,9}$ \\ ${ }^{1}$ Equipe 11 Labellisée par la Ligue Contre le Cancer, Centre de Recherche des Cordeliers, Paris, France \\ 2 INSERM, U1138, Paris, France \\ 3 Université Paris Descartes/Paris V, Sorbonne Paris Cité, Paris, France \\ ${ }^{4}$ Université Pierre et Marie Curie/Paris VI, Paris, France \\ ${ }^{5}$ Metabolomics and Cell Biology Platforms, Gustave Roussy Comprehensive Cancer Institute, Villejuif, France \\ ${ }^{6}$ Pôle de Biologie, Hopitâl Européen George Pompidou, AP-HP, Paris, France \\ 7 Department of Women's and Children's Health, Karolinska University Hospital, Stockholm, Sweden \\ ${ }^{8}$ Gustave Roussy Comprehensive Cancer Institute, Villejuif, France \\ ${ }^{9}$ Department of Radiation Oncology, Weill Cornell Medical College, New York, NY, USA \\ Correspondence to: Lorenzo Galluzzi, email: deadoc@vodafone.it \\ Keywords: ATP; chloroquine; damage-associated molecular patterns; doxorubicin; immunogenic cell death; radiation therapy \\ Received: October 27, $2016 \quad$ Accepted: November 14, $2016 \quad$ Published: December 10, 2016
}

\section{ABSTRACT}

Recent data suggest that autophagy does not influence spontaneous and therapy-elicited tumor infiltration by immune cells in murine models of melanoma and breast carcinoma. These findings, which have been obtained in the absence of a therapeutically relevant anticancer immune response, indicate that the intrinsically low immunogenicity of some tumors cannot be compensated for by increased danger signaling.

Macroautophagy (hereafter referred to as autophagy) is a highly conserved catabolic pathway though which eukaryotes preserve homeostasis at both the cellular (cellintrinsic) and organismal (cell-extrinsic) level [1,2]. Thus, autophagy continuously operates at low rates to remove cytoplasmic entities that may accumulate (and hence pose a threat) as a consequence of normal metabolism, such as redox-active protein aggregates and permeabilized mitochondria [3]. Moreover, the flux of substrates through the autophagic machinery is highly responsive to perturbations of intracellular and extracellular homeostasis as diverse as nutritional, metabolic, hormonal, physical and chemical cues [4-6]. This means that most - if not all - eukaryotic cells can adapt the rate of autophagic degradation to external stimuli, and this is a key component of adaptive stress responses [7]. In line with this notion, inhibiting autophagy with pharmacologic agents or genetic maneuvers generally precipitates (rather than retards) the death of cells experiencing potentially lethal microenvironmental perturbations $[8,9]$. Finally, autophagy contributes to the preservation of organismal homeostasis and supports healthy aging as it impacts on multiple extracellular processes with local (short-range) or systemic (long-range) outcomes [10, 11]. As a standalone example, proficient autophagic responses in muscles and in the liver are required for the beneficial effects of endurance exercise on systemic glucose metabolism [12].

Unfortunately, the pronounced capacity of autophagy to support cellular homeostasis in the course of adaptive stress responses does not benefit normal, healthy cells only $[3,13]$. Thus, autophagy not only promotes natural tumor progression as it favors the survival of malignant cells experiencing adverse microenvironmental conditions (e.g., hypoxia, reduced nutrient and growth factor availability) [14], but also promotes chemoand radioresistance (at the cell-intrinsic level) [15, 16]. Accordingly, chemical agents as well as genetic interventions targeting core components of the autophagic machinery have been shown to increase the sensitivity of cultured cancer cells to a wide panel of chemotherapeutic agents and radiotherapeutic regimens [15]. Similar findings have been obtained when the response of autophagy-competent versus autophagy-deficient cancer cells to treatment was evaluated in immunodeficient animals [15]. Throughout the past decade, all these observations generated remarkable enthusiasm on the possibility that inhibiting autophagy would mediate anticancer effects per se, or it would boost the efficacy 
of conventional chemo- and radiotherapeutic regimens $[2,17]$. The results of multiple clinical trials testing these therapeutic paradigms in cancer patients, however, have been largely disappointing [18-25].

Although several factors may underlie such a fiasco, we and others are persuaded that it relates for the most part to: (1) the too-often-disregarded cell-extrinsic effects of autophagic responses within malignant cells, and (2) the cell-intrinsic effects of autophagy in non-malignant components of the tumor environment (including immune effector cells) [15]. Proficient autophagic responses in neoplastic cells succumbing to some chemotherapeutics are indeed fundamental for optimal danger signaling, which involves the spatiotemporally ordered emission of endogenous immunostimulatory molecules commonly referred to as "damage-associated molecular patterns" (DAMPs) [26-29]. In particular, autophagy-deficient malignant cells fail to secrete ATP and to release highmobility group box 1 (HMGB1) as they die, underlying their inability to trigger tumor-targeting immune responses in the absence of exogenous adjuvants [26, 27, 30, 31]. Moreover, the activation of autophagy in dying cancer cells is required for dendritic cells to optimally process tumor-associated antigens and cross-present them to $\mathrm{CD}^{+}$cytotoxic $\mathrm{T}$ lymphocytes (CTLs) on MHC Class I molecules [32-34]. Thus, autophagy-deficient malignant cells growing in syngeneic immunocompetent hosts are generally less (rather than more) sensitive to anticancer agents that actively promote a therapeutically relevant immune response, including doxorubicin and oxaliplatin $[35,36]$, as well as to some forms of radiotherapy [37$39]$, then their autophagy-competent counterparts [26, 27, $40,41]$. Finally, autophagy is required for the survival, proliferation and activity of multiple cell populations involved in adaptive anticancer immunity, notably $\mathrm{CD} 8^{+}$ CTLs [42-46]. Taken together, these observations suggest that not only the systemic but also the local inhibition of autophagy, may limit the efficacy of antineoplastic agents that stimulate anticancer immune responses [47], at least in immunocompetent hosts (such as the vast majority of cancer patients). As a corollary of this hypothesis, it has been proposed that activating (rather than inhibiting) autophagy may boost the efficacy of cancer therapy [15]. Indeed, various nutritional interventions that potently trigger autophagy in multiple organs (including shortterm fasting, fasting-mimicking diets, and so-called caloric restriction mimetics, CRMs) turned out to improve disease outcome in a variety of rodent tumor models established in syngeneic immunocompetent hosts [40, 48-51]. Moreover, biomarkers of proficient autophagic responses in malignant cells have been associated with improved disease outcome in cohorts of breast carcinoma and multiple myeloma patients [52-54]

Irrespectively (and in spite of the considerable success achieved by multiple forms of immunotherapy throughout the past decades), many investigators and clinicians tend to perceive cancer as a cell-autonomous disorder, and hence favor the interpretation that autophagy should be inhibited in the context of cancer therapy [2]. To obtain additional insights into this issue, Starobinets and collaborators recently investigated the impact of autophagy inhibition on quantitative and qualitative aspects of the immunological tumor infiltrate in two mouse tumors models, notably B16 melanoma cells (syngeneic to $\mathrm{C} 57 \mathrm{BL} / 6$ mice) and $4 \mathrm{~T} 1$ breast carcinoma cells (syngeneic to BALB/c mice) implanted subcutaneously or orthotopically [55].

Initially, B16 and 4T1 cell variants with stable (but partial) autophagic defects imposed by the short hairpin RNA (shRNA)-mediated depletion of autophagy related 7 (Atg7) or autophagy related 12 (Atg12) were established. The stable downregulation of Atg7 or Atg12 did not affect tumor growth in immunocompetent syngeneic mice [55], contrasting with previous literature on the topic [15]. Next, spontaneous tumor infiltration by multiple populations of immune cells $\left(\mathrm{CD} 45^{+}\right.$cells, $\mathrm{CD}^{+} \mathrm{T}$ cells, $\mathrm{CD}^{+} \mathrm{CD} 4^{+}$ $\mathrm{T}$ cells, and $\left.\mathrm{CD}^{+} \mathrm{CD}^{+} \mathrm{CTLs}\right)$ [56] was determined in established (2-3 weeks after implantation) autophagycompetent versus -incompetent tumors, and no differences were found [55]. Similarly, the spontaneous $\mathrm{CD}^{+} \mathrm{CD}^{+}$ and $\mathrm{CD}^{+} \mathrm{CD}^{+}$T-cell infiltrates isolated from autophagyproficient versus -deficient B16 and 4T1 tumors growing in immunocompetent syngeneic mice did not differ with respect to an panel of activation/exhaustion markers encompassing CD44, interferon gamma (IFNG), tumor necrosis factor (TNF), granzyme B (GRZB, measured on $\mathrm{CD}^{+}$CTLs only) and programmed cell death 1 (PDCD1, best known as PD-1) [55, 57, 58].

To extend their observations to another relevant model, Starobinets and colleagues generated autophagycompetent (transfected with an irrelevant shRNA) and -incompetent (transfected with Atg7- and Atg12targeting shRNAs) B78 melanoma cells stably expressing ovalbumin (OVA) as a model antigen [55, 59]. OVAexpressing autophagy-proficient and -deficient B68 tumors developed with similar kinetics in immunocompetent C57BL/mice, and they attracted comparable amounts of adoptively transferred OVA-specific $\mathrm{CD}^{+} \mathrm{CD}^{+}$and $\mathrm{CD}^{+}{ }^{+} \mathrm{CD}^{+} \mathrm{OT}-1$ cells $[55,60]$. Moreover, $\mathrm{CD}^{+} \mathrm{CD}^{+}$and $\mathrm{CD}^{+} \mathrm{CD}^{+} \mathrm{OT}-1$ cells infiltrating autophagy-competent versus -incompetent $\mathrm{B} 68$ tumors did not differ with respect to CD44, IFNG, TNF and GRZB expression [55].

Next, the release of ATP and HMGB1 by autophagy-proficient versus -deficient B16 cells exposed to doxorubicin in vitro was monitored, confirming that doxorubicin can promote the release of these DAMPs by B16 cells in an autophagy-dependent manner. However, Starobinets and collaborators could not vaccinate $\mathrm{C} 57 \mathrm{BL} / 6$ mice with $\mathrm{B} 16$ cells succumbing to doxorubicin, irrespective of autophagic proficiency [55, $61,62]$. This in line with a previous report from our group, demonstrating that B16 cells are poorly immunogenic 
(repeated administrations of dying B16 cells was required to achieve protective immunity, to some extent) [63]. Of note, intravenous doxorubicin failed to limit the growth of autophagy-competent (and -incompetent) B16 tumors established in C57BL/6 mice. Moreover, the differential sensitivity of autophagy-proficient versus -deficient B16 cells to acute cell death induced doxorubicin in vitro was marginal at best (same sensitivity at 8 different concentrations of the drug in the $1-10 \mu \mathrm{M}$ and $20-100$ $\mu \mathrm{M}$ ranges, some extent of increased sensitivity for Atg7depleted cells at approximately 1, 10 and $50 \mu \mathrm{M}$; based on a single representative experiment) [55]. In the absence of any therapeutic effect, doxorubicin failed indeed to promote the infiltration of $\mathrm{B} 16$ tumors by $\mathrm{CD}^{+} \mathrm{CD}^{+}$and $\mathrm{CD}^{+} \mathrm{CD}^{+} \mathrm{T}$ cells, irrespective of autophagic-proficiency, although it did promote some activation in the preexisting tumor infiltrate (as per intratumoral levels of $\mathrm{CD}^{+} \mathrm{CD}^{+} \mathrm{CD} 44^{+}$and $\mathrm{CD} 3{ }^{+} \mathrm{CD} 8^{+} \mathrm{CD} 44^{+}$cells [55].

Finally, Starobinets and colleagues monitored the impact of autophagy inhibition with antimalarial drugs like chloroquine and quinacrine (which are highly nonspecific as they block lysosomal degradation) [64-68] on the growth of B16 and 4T1 cells in immunocompetent hosts [55]. Neither chloroquine nor quinacrine had an effect on tumor progression in vivo (although they did inhibit autophagy in malignant cells). Moreover, these antimalarial drugs failed to affect spontaneous tumor infiltration by $\mathrm{CD} 3{ }^{+} \mathrm{CD} 4{ }^{+}$and $\mathrm{CD} 3{ }^{+} \mathrm{CD} 8^{+} \mathrm{T}$ cells and the activation/exhaustion status of these cells [55 Apetoh, $2015,26137416]$. It is tempting to speculate that such a complete absence of response reflects (at least in part) the detrimental effects of autophagy inhibition on various populations of the immune system (including myeloid antigen-presenting cells, a compartment for which autophagy is particularly important from a functional perspective) [69-74].

In conclusion, the findings by Starobinets and colleagues suggest that autophagy-dependent DAMP signaling cannot compensate for the intrinsically low immunogenicity of some tumors (and the consequent absence of a therapeutically relevant anticancer immune response). An abundant literature demonstrates that autophagy plays a critical role in the capacity of multiple chemotherapeutic and some forms of radiation therapy to elicit anticancer immune responses that beneficially influence disease outcome (in mice and in cancer patients). Thus, in tumor models in which chemotherapy (or radiation therapy) mediates antineoplastic effects that depend on the immune system, the autophagic proficiency of malignant cells appears to support the elicitation of local, therapeutically relevant anticancer immune responses [75-79]. Moreover, in such models, nutritional interventions that potently induce autophagy at the wholebody level can boost the efficacy of chemotherapy or radiation therapy via immunological mechanisms. These experimental settings include (but are not limited to) (1) mouse MCA205 fibrosarcomas, TC1 lung carcinomas, 4T1 breast carcinomas, and CT26 colorectal cancers established in immunocompetent syngeneic mice; (2) carcinogen-driven breast carcinomas in C57BL/6 mice; and (3) $\mathrm{KRAS}^{\mathrm{G} 12 \mathrm{D}}$-induced lung carcinoma in in C57BL/6 mice $[40,50]$. In sharp contrast, as demonstrated by Starobinets and colleagues [55], when chemotherapy fails to elicit immunogenic cell death, the autophagic proficiency of malignant cells does not influence anticancer immunosurveillance (which is therapeutically irrelevant a priori).

\section{ACKNOWLEDGMENTS}

The authors are supported by the French Ligue contre le Cancer (équipe labellisée); Agence National de la Recherche (ANR) - Projets blancs; ANR under the frame of E-Rare-2, the ERA-Net for Research on Rare Diseases; Association pour la recherche sur le cancer (ARC); Cancéropôle Ile-de-France; Institut National du Cancer (INCa); Institut Universitaire de France; Fondation pour la Recherche Médicale (FRM); the European Commission (ArtForce); the European Research Council (ERC); the LeDucq Foundation; the LabEx Immuno-Oncology; the SIRIC Stratified Oncology Cell DNA Repair and Tumor Immune Elimination (SOCRATE); the SIRIC Cancer Research and Personalized Medicine (CARPEM); and the Paris Alliance of Cancer Research Institutes (PACRI).

\section{CONFLICTS OF INTEREST}

The authors declare no conflicts of interest

\section{REFERENCES}

1. Choi AM, Ryter SW and Levine B. Autophagy in human health and disease. N Engl J Med. 2013; 368(7):651-662.

2. Rubinsztein DC, Codogno P and Levine B. Autophagy modulation as a potential therapeutic target for diverse diseases. Nat Rev Drug Discov. 2012; 11(9):709-730.

3. Galluzzi L, Pietrocola F, Bravo-San Pedro JM, Amaravadi RK, Baehrecke EH, Cecconi F, Codogno P, Debnath J, Gewirtz DA, Karantza V, Kimmelman A, Kumar S, Levine $\mathrm{B}$, et al. Autophagy in malignant transformation and cancer progression. EMBO J. 2015; 34(7):856-880.

4. Efeyan A, Comb WC and Sabatini DM. Nutrient-sensing mechanisms and pathways. Nature. 2015; 517(7534):302310 .

5. Galluzzi L, Pietrocola F, Levine B and Kroemer G. Metabolic control of autophagy. Cell. 2014; 159(6):12631276.

6. Kaur J and Debnath J. Autophagy at the crossroads of catabolism and anabolism. Nat Rev Mol Cell Biol. 2015; 16(8):461-472.

7. Sica V, Galluzzi L, Bravo-San Pedro JM, Izzo V, Maiuri 
MC and Kroemer G. Organelle-Specific Initiation of Autophagy. Mol Cell. 2015; 59(4):522-539.

8. Galluzzi L, Bravo-San Pedro JM and Kroemer G. Organelle-specific initiation of cell death. Nat Cell Biol. 2014; 16(8):728-736.

9. Green DR and Levine B. To be or not to be? How selective autophagy and cell death govern cell fate. Cell. 2014; 157(1):65-75.

10. Lopez-Otin C, Galluzzi L, Freije JM, Madeo F and Kroemer G. Metabolic Control of Longevity. Cell. 2016; 166(4):802821.

11. de Cabo R, Carmona-Gutierrez D, Bernier M, Hall MN and Madeo $F$. The search for antiaging interventions: from elixirs to fasting regimens. Cell. 2014; 157(7):1515-1526.

12. He C, Bassik MC, Moresi V, Sun K, Wei Y, Zou Z, An Z, Loh J, Fisher J, Sun Q, Korsmeyer S, Packer M, May $\mathrm{HI}$, et al. Exercise-induced BCL2-regulated autophagy is required for muscle glucose homeostasis. Nature. 2012; 481(7382):511-515.

13. Guo JY, Xia B and White E. Autophagy-mediated tumor promotion. Cell. 2013; 155(6):1216-1219.

14. Noman MZ and Chouaib S. Targeting hypoxia at the forefront of anticancer immune responses. Oncoimmunology. 2014; 3(12):e954463.

15. Galluzzi L, Bravo-San Pedro JM, Demaria S, Formenti S and Kroemer G. Activating autophagy for immunogenic chemotherapy and radiation therapy. Nat Rev Clin Oncol. 2016:in press.

16. Golden EB and Formenti SC. Is tumor (R)ejection by the immune system the " 5 th $\mathrm{R}$ " of radiobiology? Oncoimmunology. 2014; 3(1):e28133.

17. Janku F, McConkey DJ, Hong DS and Kurzrock R. Autophagy as a target for anticancer therapy. Nat Rev Clin Oncol. 2011; 8(9):528-539.

18. Mahalingam D, Mita M, Sarantopoulos J, Wood L, Amaravadi RK, Davis LE, Mita AC, Curiel TJ, Espitia CM, Nawrocki ST, Giles FJ and Carew JS. Combined autophagy and HDAC inhibition: a phase I safety, tolerability, pharmacokinetic, and pharmacodynamic analysis of hydroxychloroquine in combination with the HDAC inhibitor vorinostat in patients with advanced solid tumors. Autophagy. 2014; 10(8):1403-1414.

19. Rangwala R, Chang YC, Hu J, Algazy KM, Evans TL, Fecher LA, Schuchter LM, Torigian DA, Panosian JT, Troxel AB, Tan KS, Heitjan DF, DeMichele AM, et al. Combined MTOR and autophagy inhibition: phase I trial of hydroxychloroquine and temsirolimus in patients with advanced solid tumors and melanoma. Autophagy. 2014; 10(8):1391-1402.

20. Rangwala R, Leone R, Chang YC, Fecher LA, Schuchter LM, Kramer A, Tan KS, Heitjan DF, Rodgers G, Gallagher M, Piao S, Troxel AB, Evans TL, et al. Phase I trial of hydroxychloroquine with dose-intense temozolomide in patients with advanced solid tumors and melanoma.
Autophagy. 2014; 10(8):1369-1379.

21. Rosenfeld MR, Ye X, Supko JG, Desideri S, Grossman SA, Brem S, Mikkelson T, Wang D, Chang YC, Hu J, McAfee Q, Fisher J, Troxel AB, et al. A phase I/II trial of hydroxychloroquine in conjunction with radiation therapy and concurrent and adjuvant temozolomide in patients with newly diagnosed glioblastoma multiforme. Autophagy. 2014; 10(8):1359-1368.

22. Vogl DT, Stadtmauer EA, Tan KS, Heitjan DF, Davis LE, Pontiggia L, Rangwala R, Piao S, Chang YC, Scott EC, Paul TM, Nichols CW, Porter DL, et al. Combined autophagy and proteasome inhibition: a phase 1 trial of hydroxychloroquine and bortezomib in patients with relapsed/refractory myeloma. Autophagy. 2014; 10(8):1380-1390.

23. Goldberg SB, Supko JG, Neal JW, Muzikansky A, Digumarthy S, Fidias P, Temel JS, Heist RS, Shaw AT, McCarthy PO, Lynch TJ, Sharma S, Settleman JE, et al. A phase I study of erlotinib and hydroxychloroquine in advanced non-small-cell lung cancer. J Thorac Oncol. 2012; 7(10):1602-1608.

24. Wolpin BM, Rubinson DA, Wang X, Chan JA, Cleary JM, Enzinger PC, Fuchs CS, McCleary NJ, Meyerhardt JA, Ng K, Schrag D, Sikora AL, Spicer BA, et al. Phase II and pharmacodynamic study of autophagy inhibition using hydroxychloroquine in patients with metastatic pancreatic adenocarcinoma. Oncologist. 2014; 19(6):637-638.

25. Rojas-Puentes LL, Gonzalez-Pinedo $\mathrm{M}$, Crismatt A, Ortega-Gomez A, Gamboa-Vignolle C, Nunez-Gomez R, Dorantes-Gallareta Y, Arce-Salinas C and Arrieta O. Phase II randomized, double-blind, placebo-controlled study of whole-brain irradiation with concomitant chloroquine for brain metastases. Radiat Oncol. 2013; 8:209.

26. Michaud M, Xie X, Bravo-San Pedro JM, Zitvogel L, White E and Kroemer G. An autophagy-dependent anticancer immune response determines the efficacy of melanoma chemotherapy. Oncoimmunology. 2014; 3(7):e944047.

27. Michaud M, Martins I, Sukkurwala AQ, Adjemian S, Ma Y, Pellegatti P, Shen S, Kepp O, Scoazec M, Mignot G, RelloVarona S, Tailler M, Menger L, et al. Autophagy-dependent anticancer immune responses induced by chemotherapeutic agents in mice. Science. 2011; 334(6062):1573-1577.

28. Krysko DV, Garg AD, Kaczmarek A, Krysko O, Agostinis $\mathrm{P}$ and Vandenabeele $\mathrm{P}$. Immunogenic cell death and DAMPs in cancer therapy. Nat Rev Cancer. 2012; 12(12):860-875.

29. Garg AD, Dudek AM and Agostinis P. Cancer immunogenicity, danger signals, and DAMPs: what, when, and how? Biofactors. 2013; 39(4):355-367.

30. Parodi M, Pedrazzi M, Cantoni C, Averna M, Patrone M, Cavaletto M, Spertino S, Pende D, Balsamo M, Pietra G, Sivori S, Carlomagno S, Mingari MC, et al. Natural Killer (NK)/melanoma cell interaction induces NK-mediated release of chemotactic High Mobility Group Box-1 
(HMGB1) capable of amplifying NK cell recruitment. Oncoimmunology. 2015; 4(12):e1052353.

31. Thorburn J, Horita H, Redzic J, Hansen K, Frankel AE and Thorburn A. Autophagy regulates selective HMGB1 release in tumor cells that are destined to die. Cell Death Differ. 2009; 16(1):175-183.

32. McDonnell AM, Joost Lesterhuis W, Khong A, Nowak AK, Lake RA, Currie AJ and Robinson BW. Restoration of defective cross-presentation in tumors by gemcitabine. Oncoimmunology. 2015; 4(5):e1005501.

33. Uhl M, Kepp O, Jusforgues-Saklani H, Vicencio JM, Kroemer G and Albert ML. Autophagy within the antigen donor cell facilitates efficient antigen cross-priming of virus-specific CD8+ T cells. Cell Death Differ. 2009; 16(7):991-1005.

34. Catalan E, Charni S, Jaime P, Aguilo JI, Enriquez JA, Naval J, Pardo J, Villalba M and Anel A. MHC-I modulation due to changes in tumor cell metabolism regulates tumor sensitivity to CTL and NK cells. Oncoimmunology. 2015; 4(1):e985924.

35. Pol J, Vacchelli E, Aranda F, Castoldi F, Eggermont A, Cremer I, Sautes-Fridman C, Fucikova J, Galon J, Spisek R, Tartour E, Zitvogel L, Kroemer G, et al. Trial Watch: Immunogenic cell death inducers for anticancer chemotherapy. Oncoimmunology. 2015; 4(4):e1008866.

36. Dudek AM, Garg AD, Krysko DV, De Ruysscher D and Agostinis P. Inducers of immunogenic cancer cell death. Cytokine Growth Factor Rev. 2013; 24(4):319-333.

37. Adkins I, Fucikova J, Garg AD, Agostinis P and Spisek R. Physical modalities inducing immunogenic tumor cell death for cancer immunotherapy. Oncoimmunology. 2014; 3(12):e968434.

38. Golden EB, Frances D, Pellicciotta I, Demaria S, Helen Barcellos-Hoff M and Formenti SC. Radiation fosters dosedependent and chemotherapy-induced immunogenic cell death. Oncoimmunology. 2014; 3:e28518.

39. Gameiro SR, Ardiani A, Kwilas A and Hodge JW. Radiation-induced survival responses promote immunogenic modulation to enhance immunotherapy in combinatorial regimens. Oncoimmunology. 2014; 3:e28643.

40. Pietrocola F, Pol J, Vacchelli E, Rao S, Enot DP, Baracco EE, Levesque S, Castoldi F, Jacquelot N, Yamazaki T, Senovilla L, Marino G, Aranda F, et al. Caloric Restriction Mimetics Enhance Anticancer Immunosurveillance. Cancer Cell. 2016; 30(1):147-160.

41. Ko A, Kanehisa A, Martins I, Senovilla L, Chargari C, Dugue D, Marino G, Kepp O, Michaud M, Perfettini JL, Kroemer G and Deutsch E. Autophagy inhibition radiosensitizes in vitro, yet reduces radioresponses in vivo due to deficient immunogenic signalling. Cell Death Differ. 2014; 21(1):92-99.

42. Ma Y, Galluzzi L, Zitvogel L and Kroemer G. Autophagy and cellular immune responses. Immunity. 2013; 39(2):211-
227.

43. Puleston DJ, Zhang H, Powell TJ, Lipina E, Sims S, Panse I, Watson AS, Cerundolo V, Townsend AR, Klenerman P and Simon AK. Autophagy is a critical regulator of memory CD8(+) T cell formation. Elife. 2014; 3.

44. Deretic V, Saitoh T and Akira S. Autophagy in infection, inflammation and immunity. Nat Rev Immunol. 2013; 13(10):722-737.

45. Pua HH, Dzhagalov I, Chuck M, Mizushima N and He YW. A critical role for the autophagy gene Atg5 in T cell survival and proliferation. J Exp Med. 2007; 204(1):25-31.

46. Xu X, Araki K, Li S, Han JH, Ye L, Tan WG, Konieczny BT, Bruinsma MW, Martinez J, Pearce EL, Green DR, Jones DP, Virgin HW, et al. Autophagy is essential for effector CD8(+) T cell survival and memory formation. Nat Immunol. 2014; 15(12):1152-1161.

47. Galluzzi L, Buque A, Kepp O, Zitvogel L and Kroemer G. Immunological Effects of Conventional Chemotherapy and Targeted Anticancer Agents. Cancer Cell. 2015; 28(6):690714.

48. Di Biase S, Lee C, Brandhorst S, Manes B, Buono R, Cheng CW, Cacciottolo M, Martin-Montalvo A, de Cabo R, Wei M, Morgan TE and Longo VD. Fasting-Mimicking Diet Reduces HO-1 to Promote T Cell-Mediated Tumor Cytotoxicity. Cancer Cell. 2016; 30(1):136-146.

49. Lee C, Raffaghello L, Brandhorst S, Safdie FM, Bianchi G, Martin-Montalvo A, Pistoia V, Wei M, Hwang S, Merlino A, Emionite L, de Cabo R and Longo VD. Fasting cycles retard growth of tumors and sensitize a range of cancer cell types to chemotherapy. Sci Transl Med. 2012; 4(124):124ra127.

50. Simone BA, Dan T, Palagani A, Jin L, Han SY, Wright C, Savage JE, Gitman R, Lim MK, Palazzo J, Mehta MP and Simone NL. Caloric restriction coupled with radiation decreases metastatic burden in triple negative breast cancer. Cell Cycle. 2016:1-10.

51. Saleh AD, Simone BA, Palazzo J, Savage JE, Sano Y, Dan T, Jin L, Champ CE, Zhao S, Lim M, Sotgia F, Camphausen $\mathrm{K}$, Pestell RG, et al. Caloric restriction augments radiation efficacy in breast cancer. Cell Cycle. 2013; 12(12):19551963.

52. Ladoire S, Enot D, Senovilla L, Ghiringhelli F, PoirierColame V, Chaba K, Semeraro M, Chaix M, Penault-Llorca F, Arnould L, Poillot ML, Arveux P, Delaloge S, et al. The presence of LC3B puncta and HMGB1 expression in malignant cells correlate with the immune infiltrate in breast cancer. Autophagy. 2016; 12(5):864-875.

53. Jung G, Roh J, Lee H, Gil M, Yoon DH, Suh C, Jang S, Park CJ, Huh J and Park CS. Autophagic Markers BECLIN 1 and LC3 are Associated with Prognosis of Multiple Myeloma. Acta Haematol. 2015; 134(1):17-24.

54. Ladoire S, Enot D, Andre F, Zitvogel L and Kroemer G. Immunogenic cell death-related biomarkers: Impact on the survival of breast cancer patients after adjuvant 
chemotherapy. Oncoimmunology. 2016; 5(2):e1082706.

55. Starobinets H, Ye J, Broz M, Barry K, Goldsmith J, Marsh T, Rostker F, Krummel M and Debnath J. Antitumor adaptive immunity remains intact following inhibition of autophagy and antimalarial treatment. J Clin Invest. 2016.

56. Tjin EP and Luiten RM. Tumor-infiltrating T-cells: important players in clinical outcome of advanced melanoma patients. Oncoimmunology. 2014; 3(9):e954862.

57. Kakimi K, Matsushita H, Hosoi A, Miyai M and Ohara O. CTLs regulate tumor growth via cytostatic effects rather than cytotoxicity: a few $\mathrm{T}$ cells can influence the growth of many times more tumor cells. Oncoimmunology. 2015; 4(3):e970464

58. Buferne M, Chasson L, Grange M, Mas A, Arnoux F, Bertuzzi M, Naquet P, Leserman L, Schmitt-Verhulst AM and Auphan-Anezin N. IFNgamma producing CD8+ $\mathrm{T}$ cells modified to resist major immune checkpoints induce regression of $\mathrm{MHC}$ class I-deficient melanomas. Oncoimmunology. 2015; 4(2):e974959.

59. Wylie B, Seppanen E, Xiao K, Zemek R, Zanker D, Prato S, Foley B, Hart PH, Kroczek RA, Chen W and Waithman J. Cross-presentation of cutaneous melanoma antigen by migratory XCR1+CD103- and XCR1+CD103+ dendritic cells. Oncoimmunology. 2015; 4(8):e1019198.

60. Nayar S, Dasgupta P and Galustian C. Extending the lifespan and efficacies of immune cells used in adoptive transfer for cancer immunotherapies-A review. Oncoimmunology. 2015; 4(4):e1002720.

61. Kepp O, Senovilla L, Vitale I, Vacchelli E, Adjemian S, Agostinis P, Apetoh L, Aranda F, Barnaba V, Bloy $\mathrm{N}$, Bracci L, Breckpot K, Brough D, et al. Consensus guidelines for the detection of immunogenic cell death. Oncoimmunology. 2014; 3(9):e955691.

62. Berezhnoy A, Rajagopalan A and Gilboa E. A clinically useful approach to enhance immunological memory and antitumor immunity. Oncoimmunology. 2014; 3:e28811.

63. Casares N, Pequignot MO, Tesniere A, Ghiringhelli F, Roux S, Chaput N, Schmitt E, Hamai A, Hervas-Stubbs S, Obeid M, Coutant F, Metivier D, Pichard E, et al. Caspasedependent immunogenicity of doxorubicin-induced tumor cell death. J Exp Med. 2005; 202(12):1691-1701.

64. Maycotte P, Aryal S, Cummings CT, Thorburn J, Morgan MJ and Thorburn A. Chloroquine sensitizes breast cancer cells to chemotherapy independent of autophagy. Autophagy. 2012; 8(2):200-212.

65. Eng CH, Wang Z, Tkach D, Toral-Barza L, Ugwonali S, Liu S, Fitzgerald SL, George E, Frias E, Cochran N, De Jesus R, McAllister G, Hoffman GR, et al. Macroautophagy is dispensable for growth of KRAS mutant tumors and chloroquine efficacy. Proc Natl Acad Sci U S A. 2016; 113(1):182-187.

66. Klionsky DJ, Abdelmohsen $\mathrm{K}$, Abe A, Abedin MJ, Abeliovich H, Acevedo Arozena A, Adachi H, Adams CM, Adams PD, Adeli K, Adhihetty PJ, Adler SG, Agam
$\mathrm{G}$, et al. Guidelines for the use and interpretation of assays for monitoring autophagy (3rd edition). Autophagy. 2016; 12(1):1-222.

67. Maes H, Kuchnio A, Peric A, Moens S, Nys K, De Bock K, Quaegebeur A, Schoors S, Georgiadou M, Wouters J, Vinckier S, Vankelecom H, Garmyn M, et al. Tumor vessel normalization by chloroquine independent of autophagy. Cancer Cell. 2014; 26(2):190-206.

68. Galluzzi L, Bravo-San Pedro JM, Blomgren K and Kroemer G. Autophagy in acute brain injury. Nat Rev Neurosci. 2016; 17(8):467-484.

69. Antonopoulos $\mathrm{C}$ and Dubyak GR. Chemotherapy engages multiple pathways leading to IL-1beta production by myeloid leukocytes. Oncoimmunology. 2014; 3(1):e27499.

70. Muller P, Martin K, Theurich S, von Bergwelt-Baildon $\mathrm{M}$ and Zippelius A. Cancer chemotherapy agents target intratumoral dendritic cells to potentiate antitumor immunity. Oncoimmunology. 2014; 3(8):e954460.

71. Berk E, Xu S and Czerniecki BJ. Dendritic cells matured in the presence of TLR ligands overcome the immunosuppressive functions of regulatory $\mathrm{T}$ cells. Oncoimmunology. 2014; 3:e27617.

72. Saini NK, Baena A, Ng TW, Venkataswamy MM, Kennedy SC, Kunnath-Velayudhan S, Carreno LJ, Xu J, Chan J, Larsen MH, Jacobs WR, Jr. and Porcelli SA. Suppression of autophagy and antigen presentation by Mycobacterium tuberculosis PE_PGRS47. Nat Microbiol. 2016; 1(9):16133.

73. Arguello RJ, Reverendo M, Gatti E and Pierre P. Regulation of protein synthesis and autophagy in activated dendritic cells: implications for antigen processing and presentation. Immunol Rev. 2016; 272(1):28-38.

74. Das M, Kaveri SV and Bayry J. Cross-presentation of antigens by dendritic cells: role of autophagy. Oncotarget. 2015; 6:28527-8. doi: 10.18632/oncotarget.5268.

75. Galluzzi L, Buque A, Kepp O, Zitvogel L and Kroemer G. Immunogenic cell death in cancer and infectious disease. Nat Rev Immunol. 2016.

76. Aranda F, Bloy N, Galluzzi L, Kroemer G and Senovilla L. Vitamin B6 improves the immunogenicity of cisplatininduced cell death. Oncoimmunology. 2014; 3(9):e955685.

77. Cicchelero L, Denies S, Devriendt B, de Rooster H and Sanders NN. Can dendritic cells improve whole cancer cell vaccines based on immunogenically killed cancer cells? Oncoimmunology. 2015; 4(12):e1048413.

78. Gorin JB, Guilloux Y, Morgenstern A, Cherel M, Davodeau $\mathrm{F}$ and Gaschet J. Using alpha radiation to boost cancer immunity? Oncoimmunology. 2014; 3(9):e954925.

79. Schnurr M and Duewell P. Induction of immunogenic cell death by targeting RIG-I-like helicases in pancreatic cancer. Oncoimmunology. 2014; 3(9):e955687. 